\title{
Study on Current Situations of Quality Education and Countermeasures of Private Colleges and Universities
}

\author{
Bianling Zhang \\ School of Art and Design \\ Huanghe Science and Technology College \\ Zhengzhou, China \\ e-mail: 24196102@qq.com
}

\begin{abstract}
In the twenty-first century, the competition mainly lies in science and technology, while the competition of science and technology lies in talents. It is an important task for higher education in China to cultivate high-quality talents in order to meet the needs of modernization in this new century. Now, we need more and more talents for our construction of socialist modernization, which drive us to change our examination-oriented education to quality education. With an important position in China's higher education, the quality education in private colleges and universities is faced with more severe challenges. Due to the limit of student source and defects of educational environment, private colleges and universities have some misunderstandings in quality education. It is worth us thinking deeply. Therefore, it is very important to strengthen the students' quality education in private colleges and universities. The main way is to improve the overall quality of teachers, add the content about quality education, create a good atmosphere of campus culture and emphasize students' personality development and physical and mental health.
\end{abstract}

Keywords-private colleges and universities; student characteristics; quality education; current situation; countermeasures

\section{INTRODUCTION}

Some education experts say human qualities are not only congenital, but also can be acquired through learning knowledge, ability transformation, and then are internalized as human characters. Some Suggestion to Actively Promote the Implementation of Quality Education for Primary and Middle School Pupils issued by the former State Education Commission has made a clear explanation: "the purpose of quality education is to improve the quality of our nation. It is an education based on the national education policies provided in Education Law, focusing on the long-term development of educatees and society, with facing all students and improving the basic quality of students as the fundamental purpose, with paying attention to the cultivation of educatees' attitude and ability, and promoting the development of students' morality, intelligence and physical ability as basic characteristics". It can bee seen that our quality education in China's higher education includes ideological and moral quality, cultural quality, professional quality and physical and psychological quality and etc.
In recent years, it promotes the rapid development of China's education along with the introduction of national policies and measures to encourage the private education and the rising of private universities around China, like bamboo shoots after a spring rain. As a new force in education, private colleges and universities developed fast in recent years. But there are still some imperfections possibly due to short development period. Compared with public colleges and universities, private colleges and universities are still poor in school-running conditions and student sources. The students lack self-consciousness and have great employment pressure and other problems. According to school-running features and student sources, the quality education of private colleges and universities has its own characteristics.

\section{THE CHARACTERISTICS OF STUDENTS IN PRIVATE COLLEGES AND UNIVERSITIES}

Most of students in private colleges and universities are fresh and former graduates of high school, professional high school, vocational school and technical secondary school, even a few of junior school students. The complex components form a great diversified group and show obvious characteristics.

\section{A. Caring about National Affairs and Political Affairs, but Lacking the Understanding of Some Deep-Seated Problems}

Students in private colleges and universities generally agree the party's line, policies and guidelines, care about national affairs and support the leadership of the Communist Party of China. Especially in the deepening and development of reform and opening up, it has updated students with new ideas and thoughts, improved their social responsibility and consciousness of political participation and given them absolute confidence in society and life with the gradual establishment and perfection of the socialist market economy and the strengthening of globalization and modernization. However, some of the students are indifferent to national affairs and political learning. In addition, they are poor in political theory foundation, lack certain political judgment and political acumen and understanding of some deep-seated problems and some phenomena in real life. 


\section{B. Having a Strong Sense of Inferiority and a Great} Ideological Pressure and Lacking Good Self-Adjustment

In general, private college students have a great ideological pressure, because they think that their college entrance examination scores are lower than those of students of public schools and they are students of private school. They attend "third-level" colleges and universities, so they always feel inferior and treat themselves as "second citizens". They are discriminated by the society, so they lack confidence and have a great ideological pressure, which has greatly affected their study and life. In their inner world, they yearn for new life, meanwhile they worry about the future. They hope to be understood, get care and guidance from others, but also don't want others to intervene in their personal life. Because of these negative factors, some students may lose their positive learning motivation and not withstand temporary setback and failure and not persist for a long time. According these conditions, teacher and administrators in private colleges and universities should guide students and help them establish a good selfadjustment ability.

\section{Having a Small Ambition and a Pragmatic and Positive Attitude}

Compared with public college students, students in private universities generally do not make too high ambition, but they are positive, progressive and upward to life, and eager to make a contribution to society. They pay more attention to the reality in their learning and employment, and their attitude on employment is pragmatic. But many students lack social experience, and show psychological immaturity. Their individual value hovers between noble and affordable. They lack clear understanding on new things and are easy to change their ideas and opinions. Therefore, these students should be promptly corrected and guided.

\section{Being Poor in Self-Discipline, Following Suit Blindly and Lacking Screening Ability}

Compared with public college students, students in private universities are really not good at academic performance and declining in morality. The root lies in that they do not set strict demands on themselves and develop good study habits, and have poor self-discipline. Most of the students in private colleges and universities learn what they see, but they are not skillful. The main reason is that they could not withstand the temptation of various recreational activities, lack screening ability, blindly involve in too much extracurricular activities, to the extent that they delay their studies.

\section{E. Having Prominent Advantages in Skills and Specialties and Being Unbalanced in the Development of Comprehensive Quality}

Private college students have a strong interpersonal ability and social ability, so they have a wide social circle, and are easy to accept new things. A lot of students have skills and specialties and have received professional education, so their specialties are prominent. However, they are weak in cultural foundation and have serious tendency of partiality for some subjects, so that they are unbalance in the development of comprehensive quality. It should attract high attention of private colleges and departments of education and management.

\section{SOME MisUnDERSTANDINGS IN THE IMPLEMENTATION OF QUALITY EDUCATION IN PRIVATE COLLEGES AND UNIVERSITIES}

It is an urgent task to promote the quality education of private college students in the process of reform and development of higher education under new situation. At present, no matter in the regional level or overall level, private colleges and universities have achieved remarkable results in the implementation of quality education. But it can not be ignored there still exist some misunderstandings to be clarified and aware.

Misunderstanding one: quality education refers to the education without teachers teaching.

In the practice process of quality education, private colleges and universities appeared such a phenomenon that teachers, except for teachers of professional courses, no longer seriously study materials or prepare lessons carefully. They think it can play the main role of the students to have discussion or debate in class. There is no need for teachers to teach them or explain knowledge points in the class, as long as students understand by themselves and draw a conclusion. One can imagine, it will be difficult for private college students to master knowledge and skills without teacher's preaching, teaching and dispelling doubts. Therefore, the quality education will be an empty talk.

Misunderstanding two: treating characteristic education as quality education

Some private colleges and universities think that if they do characteristic education well, their quality education to students will be also good. They may ignore the comprehension of quality education, only carry out some extracurricular recreational and sports activities, such as calligraphy lecture, music contest and sports competition, and take a one-sided understanding on the development of students' personality. Private college teachers teach students in accordance of their aptitude, but it only can care about a few students. The quality education includes ideological and moral quality, scientific and cultural quality, professional quality, psychological quality and physical quality and many other aspects. Therefore, private colleges and universities should pay attention to the all-round development of students and seriously carry out quality education. If colleges and universities deviate from the purpose of quality education, just do some formalism, stick it on the label of quality education, it will get the opposite of what one wants and turn into its opposite side.

Misunderstanding three: Quality education is only the work of educators.

Quality education is an open social and systematic engineering, which needs cooperation of all sectors of society. It not only relates to the transformation of education 
idea, the update of education concepts, but also involves the reform of curriculum system, teaching content and teaching methods as well as the development of second classroom activities and social practice activities. Therefore, it not only needs the joint efforts of educational circles, but also whole society's care and support. However, some mass media, social groups and administrative leadership believe that the implementation of quality education is only the work of educators. If things go on like this, it is detrimental to the development of quality education.

\section{THE BASIC COUNTERMEASURES OF STRENGTHENING THE QUALITY EDUCATION OF STUDENTS IN PRIVATE COLLEGES AND UNIVERSITIES}

In recent years, China's private education has obtained a huge development and formed an unique education system with a considerable scale, complete subjects and specialties and high education level. How do we cultivate private college students' quality education? How do private college students compete with public college students in the same market? These are problems to be resolved. Private colleges and universities should focus on the occupation of low-end market and the development of vocational and technical education and training education to be the base of higher education in China. With this accurate positioning, private colleges and universities can strengthen professional education and course characteristics and improve talent training quality and education service quality in order to satisfy the demands of diversified industries and categories. It is a must for current private education to grasp the pulse of the times, explore the characteristics of the training and raise education level. Private colleges and universities are products of the popularization of China's higher education and broadening school-running fund channel. The rapid development of private higher education greatly eases the contradiction between supply and demand of the talent market. Private higher education has become an important part of higher education in our country. The quality of students in private colleges and universities is not only related to their own survival and development, but also will affect the development of higher education in China. "The quality of talents training is the lifeline" has become the motto of colleges and universities at home and abroad. For private colleges, it is the lifeline of their survival and development. Therefore, it is very important to explore quality education and cultivate high-quality talents for the survival and development of private colleges and universities.

\section{A. Strengthening the Construction of Teachers and Striving to Improve the Overall Quality of Teachers}

The teacher is the spreader of human civilization and the caster of high-quality talent. It has high requirements for teachers to implement quality education. Students are unconsciously influenced by the teachers' words and deeds. The quality of teachers is the key to cultivate students with good quality. Teachers should not only be devoted to education, but also must implement the party's education policies correctly and conscientiously, and carry out comprehensive quality education for students. Teachers should strengthen the usual study and supplement knowledge timely, grasp new ideas, new knowledge and new methods constantly to adjust their knowledge structure, optimize selfquality, strength education literary, and thus improve the quality of education.

\section{B. Adding Education Content to Meet the Need of Quality Education and Constructing a Curriculum System Emphasizing Quality Education}

In the implementation of quality education, private colleges and universities should always put quality education in first place. At same time, they should strength students' professional knowledge education and carry out proper courses to improve students' culture taste and aesthetic taste. In addition, they should scientifically adjust traditional teaching content and content system, cut out subjects that are not disciplinary, add courses that can broaden students' academic view and cultural view and create conditions for interested students to attend courses and improve their quality. They can transform the knowledge-taught orientation into the knowledge-taught and scientific training orientation, with particular emphasis on scientific training.

\section{Creating a Characteristic Campus Culture and a Good Environment for Quality Education}

A unique campus culture is an important symbol of a private college's operational level and style, which unconsciously affect the formation of students' moral character, values and way of life. It has a strong guiding role. The construction of campus culture is an effective way to enrich the minds of students, improve the students' knowledge structure, strengthen and improve students' education quality in private colleges and universities. Therefore, it is suggested to create a strong atmosphere of the campus culture and a good environment for quality education, and construct an educational environment with good academic atmosphere, school spirit, elegant cultural taste and rich cultural atmosphere, so that students can receive good edification, obtain knowledge and improve their abilities in this strong academic atmosphere. It will also help develop students' specialties and hobbies and improve their quality.

\section{Strengthening Appreciation Education and Emphasizing Students' Personality Development}

With weak learning foundation, private college students lack confidence but are willing to cooperate with others. The most important thing is that they have their own special skills. These potential quality and characteristics are exactly what we need in modern society. Educational administrators should teach students in accordance with their aptitude and the characteristics of students, encourage students with a variety of incentives, discover their gifts, often praise students' advantages, encourage them to actively develop their own expertise in order to help students re-examine themselves, find themselves and become a useful person. 


\section{E. Strengthening the Psychological Education and Emphasizing Students' Physical and Mental Health}

Students in private colleges and universities, due to their own characteristics, face many psychological contradiction and confusion of life. Therefore, it is an important link to carry out psychological quality education in comprehensive quality education. As Marx said: "healthy mentality and good attitude are better than ten doses of medicine, for they can relieve pain and suffering". It will be better for private colleges and universities to carry out psychological education through various channels in all forms in class and after class, provide timely and effective psychological guidance and services and take the responsibility for students' psychological health growth. What's more, they could create more opportunities for students to participate in social practice, so that students can exercise their social adaptive ability, interpersonal coordination ability and work practice ability in rich and colorful practice. The social practice can also enhance students' courage to face difficulties and improve their ability of psychological adjustment to resist risk.

\section{REFERENCES}

[1] Zhu Yongxin. Innovative Education and Educational Innovation. Jiangsu Education Research, 2003 Vol. 6.

[2] Ma Shuping. Beijing Private Education Development and Prospect. Beijing: Jinghua Press, 2000 Edition.

[3] Higher Education Research Institute of Nankai University. Memoir on Educational Thought Discussion of Nankai University. Tianjin: Nankai University Press, 1999 Edition.

[4] Wang Lingbin. Introduction to College Students' Quality. Xi'an: Xi'an Publishing House, 2003.

[5] Feng Wanli. Discussion on the Way of the Quality Education of Contemporary College Students. Journal of Social Science of Jiamusi University, 2006 Vol. 5 